\title{
MAKNA FENOMENA KEMATIAN MASSAL DI TENGAH PANDEMI COVID-19 BERDASARKAN REFLEKSI DARI AYUB 1: 1-22
}

\author{
Eugenius Ervan Sardono, Nikodemus Hermiawan, Oktavianus Klido Wekin \\ Pascasarjana Sekolah Tinggi Filsafat-Teologi Widya Sasana Malang \\ egenjofer@gmail.com
}

\begin{abstract}
The phenomenon of mass death that occurred amid the Covid-19 pandemic made people reflect on death's meaning. Job 1: 1-22 contained a reflection on death when Job lost all of his children simultaneously to death. This research's main objective is to find the meaning of the phenomenon of mass death in the midst of a pandemic based on the book of Job 1: 1-22. The method used is qualitative with a phenomenological and hermeneutic approach. This study found the meaning of mass death amid the Covid-19 pandemic based on Job 1:1-22 is 1). the form of God's power, which must be recognized and accepted by humans; 2). the test of faith that God allows to occur in human life.
\end{abstract}

Keywords: mass death, the Covid-19 pandemic, Job 1:1-22, true faith

\begin{abstract}
Abstrak. Fenomena kematian massal yang terjadi di tengah pandemi Covid-19 membuat manusia merefleksikan kembali makna kematian. Ayub 1: 1-22 berisi refleksi tentang kematian saat Ayub kehilangan semua anaknya secara bersamaan karena kematin. Tujuan utama penelitian ini adalah menemukan makna fenomena kematian massal di tengah pandemi berdasarkan kitab Ayub 1: 1-22. Metode yang dipakai ialah kualitatif dengan pendekatan fenomenologi dan hermeneutika. Studi ini menemukan memaknai kematian massal di tengah pandemi covid-19 berdasar Ayub 1:1-22 adalah: 1). wujud dari kekuasaan Tuhan yang harus diakui dan diterima oleh manusia; 2). ujian iman yang diijinkan Tuhan untuk terjadi dalam kehidupan manusia.
\end{abstract}

Kata kunci: kematian massal, pandemi Covid-19, Ayub 1:1-22, iman yang sejati

Wabah pandemi virus corona (Covid-19) telah menjadi persoalan yang mendunia saat ini, di mana Indonesia menjadi bagian di dalamnya. Di seluruh dunia, seperti yang dirilis Kompas.com pada tanggal 1 Nopember 2020, terdapat 1.600 .984 kasus positif, sembuh sebanyak 355.671, dan jumlah kematian sebanyak 95.604 (Aida, 2020). Angka ini terus bertambah setiap hari. 
Pandemi covid-19 telah mendatangkan banyak keputusasaan dan ketidakpastian di seluruh dunia (Lazzerini \& Putoto, 2020). Kecemasan dan ketakutan dirasakan di mana-mana. Pemerintah berbagai negara menerapkan lock down atau pembatasan aktivitas sosial warganya. Masyarakat diminta tinggal di rumah, bekerja, belajar, dan beribadah di rumah. Aktivitas publik di bidang ekonomi, sosial, pendidikan, dan lain-lain, banyak yang ditutup. Krisis ekonomi menjadi ancaman serius bagi semua negara.

Bagi umat Kristen, salah satu masalah yang timbul dari pandemi Covid-19 adalah mereka terpaksa beribadah di rumah. Pada awal penerapan kebijakan ini sempat terjadi pro-kontra. Bisa terlihat pada studi yang dilakukan oleh Luhukay dalam melakukan analisis terhadap beribadah di rumah selama masa pandemi. (Luhukay, 2020). Hutahean dkk juga melakukan studi serupa perihal dampak pandemi yang membuat ruang gerak manusia terbatas, termasuk untuk beribadat (Hutahaean et al., 2020). Di Polandia, ada sebuah usaha dari para pendeta agar gerejagereja memelihara kontak dengan orang-orang percaya dengan berbagai cara, menggunakan teknologi modern dan akses ke media publik dalam hal ini. Meskipun gereja tidak mengubah posisi doktrinal mereka, mereka mendeklarasikan berbagai bentuk kerjasama. (Sulkowski \& Ignatowski, 2020).

Masalah lain yang timbul adalah tidak bisanya keluarga Kristen menyelenggarakan upacara pemakaman terhadap anggota keluarga yang 
meninggal akibat covid-19. Hal ini menjadi perhatian dari studi Wardhani dan Panuntun. Kedau penulis ini berpendapat bahwa keluarga yang mengalami duka akibat Covid-19 perlu mendapatkan perlu mendapatkan penghiburan khusus. Umat kristen tidak boleh kehilangan empati terhadap mereka. (Wardhani dan Panuntun, 2020).

Kehadiran pandemi Covid-19 juga telah menantang gereja atau umat Kristen untuk melakukan berbagai perubahan dalam pelayanan. Namun selain kedua hal di atas, ada hal penting lain yang sangat mendasar terkait dengan respon orang Kristen terhadap penyebab datangnya pandemi ini. Respon tersebut tentu berkaitan dengan teologi, doktrin, atau iman kepercayaan mereka kepada Tuhan.

Seorang penulis bernama Macneil mengajukan pertanyaan: siapakah penyebab pandemi ini, Tuhan atau iblis? la memberikan jawaban bahwa pandemi merupakan sebuah penyalahgunaan kekuasaan oleh manusia. (Macneil, 2020). Studi lain menunjukkan bahwa umat Kristen harus tetap tabah dan melihat dari kaca mata iman menghadapi pandemi ini. Ada yang menghubungkan dengan nubuatan dalam Kitab Wahyu tentang penyakit sampar. Di Korea, penyakit atau virus ini menelan banyak korban jiwa. Seolah-olah ini adalah sesuatu yang mengakhiri kehidupan. (Dein et al., 2020). Hal-hal seperti demikian tampaknya merupakan ekspresi dari orang Kristen yang bingung, heran, bercampur takut: ada apa dengan semua ini, apa sesungguhnya yang sedang terjadi? 
Pandemi ini memang menakutkan dan hal yang dirasakan paling menakutkan adalah ancaman kematian. Kematian terjadi di mana-mana dan terus bertambah setiap hari. Siapa saja bisa terinfeksi dan jika terinfeksi bisa saja tidak tertolong nyawanya. Seperti dikatakan Ingravallo, pandemi ini telah memproduksi kecemasan dan ketakutan, baik yang terinfeksi maupun yang tidak. (Ingravallo, 2020). Kematian terasa sangat dekat.

Manusia, pada umumnya, memang takut kepada kematian. Dada dan Mosooli mengemukakan bahwa ketakutan terhadap kematian merupakan fenomena universal dalam kehidupan manusia. Manusia takut pada kematian karena pada dasarnya mereka ingin hidup lebih lama, namun mereka selalu saja berhadapan dengan kenyataan akan terjadinya kematian. Mereka juga takut karena tidak bisa meramalkan kapan kematian terjadi dan jika sudah terjadi mereka tidak mampu menghalanginya. (Dada \& Mosooli, 2019).

Kematian di tengah pandemi covid-19 lebih menakutkan dari kematian sehari-hari karena terjadi secara massal dan bersifat global. Fenomena ini mau tidak mau melahirkan pertanyaan-pertanyaan mendasar tentang kehidupan dan agama dituntut memberikan jawaban agar manusia mampu memahami dan menghadapi fenomena menakutkan ini.

Agama, menurut Dada dan Mosooli, memiliki hubungan dengan ketakutan terhadap kematian karena di dalam agama umumnya terdapat 
ajaran yang berkaitan dengan kematian. Jika ajaran tersebut menempatkan kematian secara positif, lalu pemeluknya percaya dan taat pada ajaran tersebut, maka mereka akan bebas dari ketakutan terhadap kematian. (Dada \& Mosooli, 2019).

Bagaimana dengan agama Kristen? Fenomena kematian massal di tengah pandemi covid-19 tentu melahirkan berbagai pertanyaan iman. Apa yang Tuhan sedang lakukan di tengah pandemi ini? Apakah Tuhan sedang menghukum manusia karena manusia sudah banyak melakukan kejahatan? Apakah Tuhan sedang menunjukkan kuasa-Nya karena manusia sudah terlalu membanggakan dan menyombongkan kekuatannya, serta mengabaikan kemahakuasaan-Nya? Apakah Tuhan sedang menguji iman umat-Nya? Apakah Tuhan sedang meninggalkan umat-Nya? Apakah Tuhan sedang memusnahkan umat manusia? Apakah Tuhan sedang melakukan pembersihan dan pemulihan?

Pertanyaan-pertanyaan ini muncul dan mencerminkan refleksi manusia yang mendalam mengenai hakikat kehidupan, hakikat keberadaan Tuhan, dan hakikat hubungan manusia dengan Tuhan. Sebab itu gereja dan teologi Kristen harus mampu memberikan jawaban yang jelas dan pasti agar umat Kristen bisa memahami dan menghadapi fenomena kematian massal ini dengan tetap beriman kepada Tuhan.

Dalam teologi Kristen ada konsep bahwa penderitan manusia merupakan bentuk hukuman dari Allah. Seperti dikemukakan Kurniadi bahwa hal tersebut telah dinyatakan Allah dalam kisah kejatuhan manusia 
ke dalam dosa. Mereka akan menderita karena telah berbuat dosa dan melanggar hukum Allah. (Kurniadi, 2015). Namun apabila konsep ini yang diberikan untuk memaknai fenomena kematian massal akibat covid-19, maka sangat mungkin umat akan semakin hidup dalam ketakutan, kengerian, keputusasaan, dan tanpa pengharapan.

Wardhani dan Panuntun melakukan studi tentang pentingnya konseling khusus bagi keluarga duka akibat kematian pasien covid-19. Beban duka keluarga menjadi bertambah karena diberlakukannya protokol kesehatan. Keluarga tidak bisa melakukan upacara pemakaman, keluarga dan kerabat lain tidak bisa datang untuk menopang dan memberi penghiburan. Kondisi ini tentu membutuhkan pendampingan tersendiri agar keluarga mampu menerima dan melampaui duka yang dialami. (Wardhani \& Panuntun, 2020). Namun bagaimana menjelaskan secara teologis kepada keluarga duka mengenai fenomena kematian ini?

Kisah Ayub dalam Alkitab, menurut hemat penulis, menarik untuk dikaji dalam situasi ini. Kitab Ayub memberikan pengajaran yang esensial tentang bagaimana manusia memahami dan menghadapi penderitaan dalam iman yang kokoh kepada Tuhan.

Dalam Ayub 1:1-22 digambarkan bahwa Ayub adalah seorang yang saleh dan jujur, takut akan Allah, dan menjauhi kejahatan. la orang terkaya di wilayah tempat tinggalnya. la memiliki tujuh anak laki-laki dan tiga anak perempuan. Lalu suatu ketika Tuhan mengijinkan iblis mencobainya. Harta bendanya habis dirampok dan terbakar. Semua 
anaknya meninggal dunia karena tertimpa bangunan rumah yang runtuh. Digambarkan semua kejadian itu terjadi hampir bersamaan. Ayub mendapatkan semua berita mengerikan itu berturut-turut dalam satu waktu. Namun luar biasanya, Ayub hanya berdiri, mengoyak jubahnya, mencukur kepalanya, kemudian sujud dan menyembah. la berkata, "Dengan telanjang aku keluar dari kandungan ibuku, dengan telanjang juga aku akan kembali ke dalamnya. TUHAN yang memberi, TUHAN yang mengambil, terpujilah nama TUHAN!" Ayat 22 menyimpulkan dan menegaskan sikap Ayub itu bahwa "Dalam kesemuanya itu Ayub tidak berbuat dosa dan tidak menuduh Allah berbuat yang kurang patut."

Kisah Ayub pada Ayub 1:1-22 ini menunjukkan bahwa Ayub mampu melihat secara positif semua kemalangan, bencana, nestapa, dan penderitaan yang dialaminya. la tetap beriman teguh kepada Tuhan dan tidak menyalahkan Tuhan.

Djogo melakukan studi terhadap kisah Ayub ini dalam kaitan dengan penderita HIV/AIDS sebagai sebuah fenomena kemanusiaan. Dari hasil studinya berkesimpulan bahwa penderitaan dikaitkan kedaulatan Allah atas seluruh kosmos dan atas ciptaan-Nya. Manusia mungkin menyalahkan Allah atas penderitaan yang dialaminya, namun pada titik tertentu, penderitaan adalah misteri ilahi yang tidak bisa dipahami dan dicerap oleh akal manusia secara utuh. Allah adalah hakim atas segala sesuatu. (Djogo, 2017). 
Studi Stefanus dan Marbun tentang penderitaan Ayub juga memperlihatkan bahwa penderitaan bisa dialami siapa saja. Orang jujur dan orang benar pun tidak akan luput dari penderitaan. Makna penderitaan Ayub bagi iman orang percaya, antara lain: pertama, bahwa orang Kristen tidak terlepas dari realitas penderitaan. Kedua: Iman orang Kristen akan diuji Tuhan. Ketiga: Tuhan adalah Tuhan yang Mahaadil, tidak ada kecurangan dalam diri-Nya. Keempat: Penderitaan orang Kristen ada dalam batas dan pengawasan Tuhan, sehingga tidak satu pribadi maupun kuasa apapun yang dapat menjamah orang percaya, jika tidak mendapat ijin-Nya. (Stevanus \& Marbun, 2019).

Pendapat Stevanus melalui kajian ini dapat disimpulkan bahwa Allah berdaulat atas segala sesuatu dan tidak ada peristiwa yang terjadi secara kebetulan, tapi ada rencana Tuhan di dalamnya. Oleh karenanya, bercermin dari pengalaman Ayub tersebut, penting melakukan refleksi diri dan sekaligus penyerahan diri sehingga pada akhirnya tidak mengalami keputusasaan di tengah penderitaan. (Stevanus, 2019)

Kesimpulan dari kedua hasil penelitian di atas tersebut adalah bahwa penderitaan dialami oleh semua orang dan penderitaan juga adalah ujian iman bagi orang yang percaya. Meskipun demikian masih ada pertanyaan yang belum terjawab: mengapa pandemi ini terjadi dan merenggut nyawa banyak orang? Jika ini hanya sekedar ujian iman, mengapa Tuhan harus merenggut nyawa begitu banyak orang? Jika 
Tuhan ingin menguji iman saya mengapa la harus mengambil nyawa banyak orang yang saya kasihi?

Jawaban atas pertanyaan ini, menurut hemat penulis, masih bisa digali dari kisah Ayub :1-22. Bagaimana fenomena kematian massal akibat pandemi covid-19 direfleksikan dari kisah ini? Apa makna penting dari Ayub :1-22 bagi umat Kristen dalam menghadapi fenomena kematian massal akibat covid-19? Studi ini penting dilakukan untuk memberikan kekuatan dan pengharapan bagi umat Kristen, sebagai bagian dari seluruh umat manusia di dunia, yang sedang berjuang menghadapi pandemi covid-19.

\section{METODE}

Dalam melakukan penelitian ini, penulis menggunakan metode penelitian kualitatif dengan dua pendekatan. Pendekatan pertama adalah fenomenologi. Studi fenomenologi adalah suatu usaha mencari makna dari suatu fenomena, yaitu suatu realitas yang tampak dan berada dalam persepsi atau kesadaran manusia. Fokus penelitian fenomenologi adalah apa yang dialami subyek penelitian dan bagaimana subyek mengalami dan memaknai pengalaman tersebut. (Hasbiansyah, 2008).

Fenomena yang dimaksud adalah kematian massal di tengah pandemi covid-19. Namun fokus penelitiannya bukan lagi pada apa dan bagaimana fenomena kematian massal dialami, melainkan bagaimana fenomena kematian massal itu dimaknai. Makna tersebut digali dari teks 
Alkitab Ayub 1:1-22. Sebab itu, penulis menggunakan pendekatan kedua yaitu studi hermeneutika.

Dalam studi hermeneutika penulis mengikuti konsep Friedrich Schleiermacher tentang lingkaran hermeneutika. Seperti diuraikan oleh Verdianto, metode ini merupakan tafsir gramatikal terhadap teks. Penafsir harus memeriksa kata-kata dalam konteks kalimat, lalu kalimat dalam konteks paragraf, dan seterusnya, sampai mendapatkan pemahaman yang akurat terhadap teks. Artinya, penafsir hanya akan dapat menemukan makna teks secara utuh dengan memahami maknanya dari kata-kata atau kalimat individu dalam teks yang ditafsirkan. Namun di sisi lain, penafsir juga tidak akan dapat memahami bagian-bagian individual dengan benar selain memahaminya secara menyeluruh. (Verdianto, 2020). Penulis akan menafsirkan teks Ayub 1:1-22 dengan menggali maknanya pada setiap kata, kalimat, lalu perikop ini secara utuh. Setelah menemukan makna secara utuh, penulis akan kembali melihat makna pada setiap kata dan kalimat yang ada di dalamnya.

Dalam penggunaan tafsir gramatikal tersebut, penulis mempertimbangkan pendapat Hans Gadamer mengenai bahasa dalam hermeneutika. Menurut Gadamer, semua pemahaman berakar dalam bahasa. la mengklaim bahwa pemahaman hermeneutika terjadi ketika teks dan penafsirnya saling menyatu. Sebab itu, penafsir teks harus jeli dalam memahami makna tersembunyi dari bahasa yang diungkapkan oleh penulis teks. (Verdianto, 2020). 
Artinya, pemahaman yang akan dicari dalam teks tidak terlepas dari pemahaman penafsir terhadap situasi yang sedang menjadi perhatiannya. Penafsir menafsirkan teks untuk mencari pemahaman tentang situasi yang sedang dihadapinya. Dalam penelitian ini yang menjadi perhatian penafsir adalah fenomena kematian massal akibat pandemi covid-19. Sebab itu, penulis akan menafsirkan teks Ayub 1:1-22 untuk mencari makna femonena kematian massal tersebut.

\section{HASIL}

Dari penelitian yang dilakukan, terdapat dua hal utama dalam refleksi terhadap makna fenomena kematian massal akibat covid-19 dari perspektif Ayub 1:1-22. Pertama, kematian massal di tengah pandemi covid-19 merupakan bukti kekuasaan Allah atas kehidupan dan kematian manusia. Ayub memahaminya demikian melalui pernyataannya, "Dengan telanjang aku keluar dari kandungan ibuku, dengan telanjang juga aku akan kembali ke dalamnya. TUHAN yang memberi, TUHAN yang mengambil, terpujilah nama TUHAN!" Ayub menerima kekuasaan Allah itu dengan rendah hati sehingga ia mampu menghadapi dan menerima kehilangan harta dan benda dan kematian semua anaknya dengan lapang dada, bahkan dengan pujian syukur kepada Tuhan.

Kedua, kematian massal dalam pandemi covid-19 merupakan ujian iman yang diijinkan Tuhan terjadi dalam kehidupan manusia. Ini terlihat dalam percakapan Allah dengan iblis. Ayub adalah seorang yang saleh 
dan jujur, takut akan Allah, dan menjauhi kejahatan. Apakah ia akan tetap hidup demikian meskipun segala miliknya, termasuk orang-orang yang sangat dikasihinya, diambil Tuhan? Kesimpulannya terdapat dalam ayat 22 yang menegaskan sikap Ayub bahwa "Dalam kesemuanya itu Ayub tidak berbuat dosa dan tidak menuduh Allah berbuat yang kurang patut." Ayub lulus dalam ujian iman tersebut.

\section{PEMBAHASAN}

\section{Penerimaan Ayub Terhadap Kekuasaan Allah Atas Kematian}

Apabila kita mendengar kata 'nabi', dibayangan sosok manusia pilihan Allah. Sebagai manusia biasa, Ayub memiliki keistimewaan dalam memandang fenomena kematian. la tidak menunjukkan ketakutan. Ini tercermin dari ucapannya: "Dengan telanjang aku keluar dari kandungan ibuku, dengan telanjang juga aku akan kembali ke dalamnya. TUHAN yang memberi, TUHAN yang mengambil, terpujilah nama TUHAN!"

Pandangan Ayub ini bertolak belakang dengan pendapat yang melihat penderitaan dan kematian sebagai "ketidakmampuan Allah" atau Nietzsche yang melantangkan kematian Allah. (Nurul Anam, 2020). Pandangan Ayub mengenai kematian lebih sejalan dengan pandangan Rahner. Filsuf ini merefleksikan bahwa kematian merupakan sebuah peristiwa yang secara nyata ada dan dialami oleh seluruh manusia. Bagi Rahner, kematian merupakan sesuatu yang terjadi di sini dan saat ini (hic 
et nunc). Sebab itu manusia perlu menerima kematian sebagai bagian dari realitas yang harus dihadapinya.(Pradipta, 2019).

Ayub mampu menerima kematian yang menimpa orang-orang yang dikasihinya karena penerimaannya terhadap kekuasaan Tuhan atas kehidupan dan kematian manusia. Bagi Ayub, semua yang dimiliki manusia adalah kepunyaan Tuhan. Pada hakekatnya manusia tidak punya apa-apa. Jika manusia bisa hidup dan memiliki sesuatu semua karena Tuhan.

Fenomena kematian massal dalam pandemi covid-19 sulit dimengerti dan diterima oleh batas pemikiran manusia. Mengapa semua ini terjadi, itulah rahasia Tuhan. Namun jika manusia bisa menerima bahwa Tuhan berkuasa atas kehidupan dan kematian manusia, maka mereka tidak perlu merasa kecewa, putus asa, dan takut menghadapi fenomena tersebut.

\section{Kematian Massal di Hadapan Iman yang Tahan Uji}

Dalam Ayub 1:1-22 tampaklah bahwa semua kemalangan yang dialami Ayub merupakan ujian iman yang diijinkan Tuhan untuk terjadi dalam hidupnya. Ini mematahkan asumsi bahwa kemalangan hidup merupakan akibat dosa dan bahwa orang baik tidak akan mungkin mendapatkan kemalangan dalam hidup. Ayub adalah seorang yang saleh dan jujur, takut akan Allah, dan menjauhi kejahatan, namun ia mendapatkan kemalangan yang mengerikan. 
Faktanya dalam kehidupan sehari-hari banyak orang berusaha hidup benar dengan harapan akan terlepas dari berbagai penderitan hidup. Jika penderitaan terjadi pada orang baik, benar, dan saleh maka seperti dikemukakan Rumbi, kehendak Allah akan digugat. la dianggap tidak berpihak pada yang menderita. (Rumbi, 2019).

Kisah tentang Ayub berbicara mengenai cara beriman kepada Tuhan. Iman Ayub didasarkan pada penerimaan akan kekuasaan Tuhan dalam hidupnya, bukan demi untuk mendapatkan sesuatu dari Tuhan. Ayub mengimani bahwa apa yang dimiliknya semua bersumber dari Tuhan sebab itu imannya tidak goyah sedikit pun meskipun ia kehilangan hampir segala-galanya, termasuk kehilangan semua orang yang sangat dikasihinya.

Apakah fenomena kematian massal dalam pandemi covid-19 merupakan ujian iman? Jika dilihat dari perikop ini maka jawabannya adalah ya. Pemaknaan bahwa kematian massal dalam pandemi covid-19 merupakan sebuah ujian iman mestinya akan memampukan setiap orang untuk tetap percaya dan berharap kepada Tuhan sebab pada hakekatnya kehidupan dan kematian adalah otoritas Tuhan.

Mengapa manusia menderita menghadapi fenomena kematian seperti itu? Jawabnya karena mereka tidak mampu menerima otoritas Tuhan atas kehidupan dan kematian dengan iman yang teguh. Tuhan tidak mendatangkan penderitaan melalui kematian, tapi penderitaan dirasakan manusia karena penolakan terhadap otoritas Tuhan atas 
kehidupan dan kematian. Sama seperti Ayub, siapa yang beriman teguh akan tetap bersukacita menghadapi kematian.

Jika merujuk pada kisah penciptaan, penderitaan manusia diyakini tidak bersumber dari Allah. Allah yang Mahabaik telah menciptakan segala sesuatu "baik adanya". Penderitaan adalah sesuatu yang "tidak baik", jadi tidak mungkin berasal dari Allah. (Hidayat, 2017).

Allah bukanlah pihak yang bisa dianggap bertanggungjawab atas kemalangan hidup yang menimpa manusia. Manusia tidak boleh menyalahkan Allah. Apalagi kemalangan yang timbul akibat kesalahan manusia itu sendiri. Menurut Lukito, manusia seringkali mempersalahkan Tuhan karena manusia hanya menginginkan Allah menurut kategori, ukuran, angan-angan, atau harapan dalam pikiran mereka sendiri. (Lukito, 2020).

Ayub tidak menyalahkan Allah atas kemalangan yang menimpa hidupnya. la menerima bahwa apa yang terjadi adalah kekuasaan Tuhan namun ia tidak menyalahkan Tuhan. Tampaknya inilah kekuatan Ayub. Inilah kesejatian imannya kepada Tuhan.

Penolakan terhadap penderitaan sebagai ujian iman yang berasal dari Allah bisa menimbulkan konflik iman. Sebab jika penderitaan tidak berasal dari Allah, mengapa Allah yang Mahakuasa tidak segera melenyapkan penderitaan ini? Mengapa Allah yang Mahakuasa membiarkan pandemi covid-19 terus merajalela dan mengakibatkan 
kematian massal yang mengerikan? Bukankah dengan kemahakuasaanNya Allah bisa segera menghentikan pandemi ini?

Rasul Paulus dalam Filipi 1:21 menulis: "Karena bagiku hidup adalah Kristus dan mati adalah keuntungan." Kata kuncinya adalah “Kristus." Menurut Yohanes Calvin (1509-1564), "Kristus” harus menjadi subjek dan predikatnya adalah "keuntungan" (jadi predikatnya tidak boleh "hidup [bersama Kristus]" dan "mati [memperoleh keuntungan]"). Jadi yang tampak menonjol pada ayat ini adalah frasa: "Kristus [adalah] keuntungan." (Lukito, 2020).

Dalam konsep Rasul Paulus tersebut, baik hidup maupun mati, semuanya adalah keuntungan di dalam Kristus. Kematian dan kehidupan sama nilainya di dalam Kristus. Hal ini sejalan dengan konsep Ayub bahwa kehidupan dan kematian sama-sama adalah kekuasaan Tuhan.

Apabila hal ini diimani maka iman orang percaya tidak akan goyah menghadapi fenomena kematian massal di tengah pandemi covid-19. Fenomena itu bukanlah kesalahan Tuhan, bukan karena la tidak peduli, dan bukan karena ia tidak memiliki otoritas di dalamnya. Fenomena ini adalah wujud dari kekuasaan Tuhan bahwa kematian dan kehidupan adalah kekuasaan Tuhan.

\section{KESIMPULAN}

Berdasarkan refleksi dari Ayub 1:1-22, makna fenomena kematian massal di tengah pandemi covid-19 adalah bahwa kematian tersebut 
merupakan wujud kekuasaan Tuhan atas kematian dan kehidupan manusia serta ujian iman bagi umat percaya. Apabila manusia bisa mengakui dan menerima kekuasaan Tuhan atas kematian dan kehidupan manusia maka mereka tetap akan beriman teguh kepada Tuhan di tengah fenomena kematian massal tersebut.

Makna seperti ini mestinya akan memberikan kekuatan bagi umat yang percaya kepada Tuhan untuk tidak cemas, kuatir, dan takut berada di tengah-tengah pandemi covid-19. Sambil terus terlibat bersama dengan semua orang dalam upaya memutus mata rantai penyebaran virus, maka umat Kristen dapat menularkan semangat, keyakinan, dan pengharapan kepada semua orang.

\section{DAFTAR PUSTAKA}

Aida, N. R. (2020, November 1). Update Corona Global: 46,3 Kasus Juta Positif / Slovakia Uji Covid-19 pada Anak Usia 10 Tahun ke Atas. Kompas.com.

https://www.kompas.com/tren/read/2020/11/01/070100565/updatecorona-global--46-3-kasus-juta-positif-slovakia-uji-covid-19-pada

Dada, R., \& Mosooli, E. A. (2019). Konsep Agama Suku Wana Tentang Kematian, Implikasinya Bagi Misi Kristen di Wana. Visio Dei: Jurnal Teologi Kristen, 1(2), 200-221. https://doi.org/10.35909/ visiodei.v1i2.54

Dein, S., Loewenthal, K., Lewis, C. A., \& Pargament, K. I. (2020). COVID19, Mental Health and Religion: An Agenda for Future Research. Mental Health, Religion \& Culture, 23(1), 1-9. https://doi.org/10.1080/13674676.2020.1768725

Djogo, E. S. M. Da. (2017). Tinjauan Permasalahan Teodise Kitab Ayub dan Relevansinya Terhadap Penderita HIV/AIDS. Melintas, 33(3), 342-369. 
Hasbiansyah, O. (2008). Pendekatan Fenomenologi: Pengantar Praktik Penelitian dalam IImu Sosial dan Komunikasi. Mediator: Jurnal Komunikasi, 9(1), 163-180.

Hidayat, E. A. (2017). Iman di Tengah Penderitaan: Suatu Inspirasi Teologis-Biblis Kristiani. MELINTAS, 32(3), 285-308. https://doi.org/10.26593/mel.v32i3.2695.285-308

Hutahaean, H., Silalahi, B. S., \& Simanjuntak, L. Z. (2020). Spiritualitas Pandemik: Tinjauan Fenomenologi Ibadah Di Rumah. Evangelikal: Jurnal Teologi Injili dan Pembinaan Warga Jemaat, 4(2), 235-250. https://doi.org/10.46445/ejti.v4i2.270

Ingravallo, F. (2020). Death in the Era of the COVID-19 Pandemic. Correspondence, 5(5), e258. https://doi.org/10.1016/S24682667(20)30079-7

Kurniadi, B. W. (2015). Inspirasi Kisah Ayub bagi Seorang Katolik dalam Menghadapi Penderitaan. MELINTAS, 31(1), 47. https://doi.org/10.26593/mel.v31i1.1455.47-62

Lazzerini, M., \& Putoto, G. (2020). COVID-19 in Italy: Momentous Decisions and Many Uncertainties. Correspondence, 8(5), e641e642. https://doi.org/10.1016/S2214-109X(20)30110-8

Lukito, D. L. (2020). Iman Kristen di Tengah Pandemi: Hidup Realistis Ketika Penderitaan dan Kematian Merebak. LP2M STT SAAT.

Macneil, M. (2020). COVID-19 Novel Coronavirus: God's Blessing or Satan's $\quad$ Curse? 10.13140/RG.2.2.18360.70407/1. https://www.researchgate.net/publication/340772114_COVID19_Novel_Coronavirus_God's_Blessing_or_Satan's_Curse

Pradipta, N. (2019). Belas Kasih Allah dalam Kematian Kristiani Menurut Karl Rahner. Jurnal Teologi, 8(1), 47-64.

Rumbi, F. P. (2019). Babak Akhir Penderitaan, Dosa, dan Teodice dalam Epilog Kitab Ayub 42:7-17. Veritas Lux Mea: Jurnal Teologi dan Pendidikan Kristen, 1(2), 53-64.

Stevanus, K. (2019). Kesadaran Akan Allah Melalui Penderitaan Berdasarkan Ayub 1-2. Dunamis: Jurnal Teologi dan Pendidikan Kristiani, 3(2), 112-134.

Stevanus, K., \& Marbun, S. M. (2019). Memaknai Kisah Ayub Sebagai Refleksi Iman Dalam Menghadapi Penderitaan. LOGIA: Jurnal Teologi Pentakosta, 1(1), 23-41. 
Sulkowski, L., \& Ignatowski, G. (2020). Impact of COVID-19 Pandemic on Organization of Religious Behaviour in Different Christian Denominations in Poland. Religions, 11(5). https://doi.org/10.3390/rel11050254

Verdianto, Y. (2020). Hermeneutika Alkitab Dalam Sejarah: Prinsip Penafsiran Alkitab Dari Masa ke Masa. Mitra Sriwijaya: Jurnal Teologi dan Pendidikan Kristen, 1(1), 45-57.

Wardhani, L. P. K., \& Panuntun, D. F. (2020). Pelayanan Pastoral Penghiburan Kedukaan bagi Keluarga Korban Meninggal Coronavirus Disease 2019 (COVID-19). KENOSIS: Jurnal Kajian Teologi, 6(1), 43-63. https://doi.org/10.37196/kenosis.v6i1.98 